\title{
Endomyocardial biopsy
}

\author{
E. G. J. OLSEN
}

From the National Heart Hospital, Westmoreland Street, London

Biopsy has proved to be of great diagnostic value in organs such as the kidney and liver, but in the case of the heart biopsy techniques have not been widely used, probably because of its function as a pump and the consequent risk of complications. Many methods have been devised to obtain fresh myocardial tissue (with endo- and/or pericardium) from living patients. These include percutaneous techniques, using a variety of specially adapted needles, catheter biopsy techniques, exploratory mediastinotomy, and thoracotomy (Olsen, 1977a). The use of an endomyocardial bioptome has been increasing in popularity. The first bioptome was devised by Sakakibara and Konno (1962) and described in detail by Konno and Sakakibara (1963), and others have adapted instruments devised for other purposes (Ali, 1974; Caves et al., 1974a; Richardson, 1974). After the reports of Sekiguchi and Konno (1969, 1971), papers have appeared from many countries, including Uganda (Somers et al., 1971), West Germany (Harmjanz et al., 1971; Kuhn et al., 1975), East Germany (Müller et al., 1971), France (Kin et al., 1973; Bouhour et al., 1976; Petitier et al., 1976), Sweden (Torp, 1973), U.S.A. (Ali et al., 1973; Ali, 1974; Caves et al., 1974b), and Great Britain (Brooksby et al., 1974, 1975; Olsen, 1974, 1975; Richardson, 1974, 1975; MacKay et al., 1974, 1978).

\section{Complications}

In experienced hands the use of a bioptome appears to be safe. Unpleasant sensations, chest discomfort, and pain occur in a few cases (Somers et al., 1971; Sekiguchi et al., 1972/73; Brooksby et al., 1974; Richardson, 1975; Petitier et al., 1976), particularly at the moment of taking the biopsy (Sekiguchi et al., 1972/73). Richardson (1975) observed short runs of atrial fibrillation or multiple ventricular premature contractions in a series of 170 patients; in 1 patient supraventricular tachycardia produced left ventricular failure and required DC conversion; occasionally the procedure was followed by pericardial pain, in 2 instances associated with a pericardial rub. Brooksby et al. (1974, 1975) described only 3 more serious complications in over 100 patients; insignificant haemopericardium occurred in 2 patients and ventricular tachycardia requiring electroversion in 1. Right-sided pneumothorax has occasionally been encountered (Caves et al., 1974b) and very rarely haemopericardium (Brooksby et al., 1974). C. Oakley (1977, personal communication) has found no morbidity or mortality in over 90 patients personally biopsied. Thus, multiple ventricular biopsy specimens can be obtained with this technique with relative ease and safety. This has opened up exciting possibilities for analysing fresh endomyocardial tissue.

Enzymic analysis Peters et al. (1975) have reported biochemical assay studies on patients with cardiomyopathy: there was a significant reduction in mitochondrial glutamate and malate dehydrogenase particularly in biopsy specimens from patients with poor left ventricular function, compared with control myocardium obtained at open heart surgery. They also found low levels of myofibrillar azideresistant calcium-dependent ATPase and a significant increase in cytosol lactate dehydrogenase levels. These findings indicated mitochondrial and myofibrillar abnormalities in myopathic tissue. There were no microsomal, lysosomal, or sarcolemmal enzyme changes in these biopsies. Peters et al. (1976) also studied patients with valvar heart disease, correlating enzyme assays on left ventricular endomyocardial biopsy material with left ventricular function. In patients with poor function, myofibrillar calcium-dependent ATPase was strikingly decreased and cytosol lactic dehydrogenase was significantly increased. 


\section{Virus and immunological studies}

There have been very few reports of the successful isolation of viruses (Kuhn et al., 1975). Immunological studies are also being done (Bolte, 1978). Examination of biopsy material has also proved of value in combating rejection episodes in patients who have undergone cardiac transplantation (Caves et al., 1974b).

\section{Cardiomyopathy}

In most larger series, a substantial number of patients have been included who were thought to be suffering from a form of cardiomyopathy, the term being used for the condition previously known as 'primary cardiomyopathy' (Goodwin, 1973) and defined as 'heart muscle disease of unknown cause or association' (Oakley, 1975).

\section{HYPERTROPHIC CARDIOMYOPATHY}

The morphological changes in hypertrophic cardiomyopathy are diagnostic. Applying the criteria established from a study of tissue obtained at operation or necropsy (Teare, 1958; Van Noorden et al., 1971), we found it possible to confirm the clinical diagnosis by biopsy in 17 (38\%) of 45 patients, but no pathological confirmation was obtained in 18 $(40 \%)^{1}$ patients. In the first group, the biopsy is of value to the referring physician, because it provides support for the clinical diagnosis. On the other hand, in the absence of morphological evidence, the clinical suspicion is not substantiated, assuming that when multiple biopsy specimens are obtained these will include representative areas. In 9 patients $(20 \%)$ there were some morphological features of hypertrophic cardiomyopathy, but the changes were not diagnostic, the histological HOCM index (Van Noorden et al., 1971) being below 30 per cent. In the remaining patient, insufficient material was obtained. In many patients with hypertrophic cardiomyopathy, a firm diagnosis can be established from the clinical features and by noninvasive investigation, but occasionally a firm diagnosis cannot be made by these means and biopsy examination should then be combined with haemodynamic and angiographic study.

Asymmetric hypertrophy of the interventricular septum may also be found in association with congenital cardiac malformation, but morphological examination failed to show histopathological characteristics of hypertrophic cardiomyopathy in 6 of 8 such patients examined (Maron et al., 1975). In

${ }^{1}$ Results reported in brief to the British Cardiac Society (Olsen, 1977b) another series, disproportionate interventricular septal thickening was noted on echocardiographic examination in a variety of cardiac conditions. Clinical follow-up over a period of one to two years showed resolution of the interventricular septal thickening in patients other than those suffering from hypertrophic cardiomyopathy (Larter et al., 1976). Thus, asymmetric hypertrophy of the interventricular septum does not necessarily constitute hypertrophic cardiomyopathy, and bioptome examination would be valuable in these cases if resolution fails to take place.

\section{CONGESTIVE CARDIOMYOPATHY}

Great difficulty is experienced in evaluating biopsy material in patients thought to have a congestive cardiomyopathy, because of the absence of any specific morphological features other than those of a dilated, hypertrophied heart. In patients with cardiac enlargement, Somers et al. (1971) found examination of biopsy material helpful in distinguishing endomyocardial fibrosis from congestive cardiomyopathy. This distinction is important not only in tropical regions, but also in temperate zones, as there is persuasive evidence that Löffler's endocarditis and endomyocardial fibrosis belong to the same disease spectrum (Roberts et al., 1969; Brockington and Olsen, 1973). The absence of any specific morphological features makes a diagnosis of congestive cardiomyopathy unsatisfactory (MacKay et al., 1978), but the clinical diagnosis of congestive cardiomyopathy is made by the exclusion of other conditions which may result in a dilated heart, and likewise a morphological diagnosis is made by exclusion of conditions such as myocarditis, small vessel disease, and degenerative and infiltrative diseases of the myocardium. Even if nothing is found other than the morphological features of a dilated, hypertrophied heart, this observation helps to confirm the suspected diagnosis; no better diagnostic method is available at present. Confirmation of the diagnosis of congestive cardiomyopathy was possible in 92 of 188 patients (Olsen, 1977b). In 46 patients there were none of the morphological features usually seen in dilated hearts, but in 8 of these there was myocarditis and in 3 hypertrophic cardiomyopathy or small vessel disease. In 32 patients normal morphology or minor hypertrophic changes were seen; these patients may be in a latent phase of congestive cardiomyopathy, but close clinical follow-up and sequential biopsies would help to define the natural history of congestive cardiomyopathy, about which so little is known. There was insufficient material for pathological assessment in 18 patients. Kuhn et al. (1975) reported myocarditis in 5 of 25 patients thought to have congestive cardiomyopathy, 
and storage disease in 1 patient.

There is, therefore, evidence that in patients thought clinically to have congestive cardiomyopathy, other disease processes may be found. In 10 per cent of the cases reported by MacKay et al. (1978), morphological examination altered the clinical diagnosis, and thus treatment and prognosis. These observations alone justify the continued use of biopsy investigation of these patients.

An attempt to evaluate prognosis in congestive cardiomyopathy has been made by Kuhn et al. (1975) by ultrastructural examination of biopsy material, using a scoring system awarding points to degenerative changes, myofibrillar disorientation, new formation of myofilaments, interstitial fibrosis, and hypertrophy. Patients were divided into two groups, those with a score of 4 points or less and those with 5 points or more. A low mortality rate in the first group and a high rate in the second group was found after a mean follow-up period of nearly 12 months. They concluded that assessment of prognosis was possible on ultrastructural examination, but Bouhour and his colleagues (1976) were more cautious. They stressed the nonspecific pathological changes in congestive cardiomyopathy, but found varying degrees of fibrosis in the biopsy material, correlating well with the length of history, so that the longer the patients had suffered from congestive cardiomyopathy, the greater the degree of fibrosis (Petitier et al., 1976).

\section{Role of endomyocardial biopsy}

As a general rule biopsy should be undertaken if there is doubt about the clinical diagnosis of myocardial disease. Good results can be expected if the disease process is widespread, as in congestive cardiomyopathy, acute rejection, and in most cases of myocarditis, or if the lesion can be accurately located, as in asymmetric hypertrophy, intracardiac tumours, and in patients with Löffler's endocarditis or endomyocardial fibrosis in whom the endocardial contour may be irregular (Olsen, 1976). Biopsy confirmation of the suspected diagnosis makes a helpful and positive contribution (Somers et al., 1971; Olsen, 1974, 1976, 1977b; Kuhn et al., 1975).

The representativeness of biopsy samples and the superiority of right or left ventricular biopsies depend on the distribution of the lesion. Brooksby et al. (1974) found a difference between right and left ventricular samples in 60 per cent of 20 patients, some of whom suffered from aortic and mitral valve disease. On the other hand, in the series of Richardson et al. (1975), which consisted mainly of patients with suspected congestive cardiomyopathy, there were no significant differences between right and left ventricular samples in the majority. Final confirmation of whether the biopsy samples reflect accurately the changes occurring in the rest of the myocardium depends upon postmortem examination of the heart, but this has been obtained only in a few cases. A good correlation between biopsy and postmortem diagnoses has been found by Sekiguchi and Konno (1971) in 15 patients, by Olsen (1977b) in 7 out of 9 patients, and by MacKay et al. (1978) in 4 of their cases.

\section{Conclusion}

In the present state of knowledge, particularly of cardiomyopathies, there is ample reason for continuing to employ endomyocardial biopsy technique. This opinion is based not only on reported cases, but also on personal experience of the examination of multiple ventricular samples from nearly 400 patients received from various British and Continental centres. Even if the morphological examination merely confirms the clinical diagnosis, this is of value. Accurate morphological diagnosis and observation of the distribution of the various constituents of the endomyocardial sample are essential for the interpretation of biochemical or other analyses made on these biopsies.

Support from the British Heart Foundation is acknowledged, and I also thank those colleagues from Britain and other European countries who have sent me the biopsy material.

\section{References}

Ali, N. (1974). Transvenous endomyocardial biopsy using the gastrointestinal biopsy (Olympus GFB) catheter. American Heart fournal, 87, 294-297.

Ali, N., Ferrans, V. J., Roberts, W. C., and Massumi, R. A. (1973). The clinical evaluation of transvenous catheter technique for endomyocardial biopsy. Chest, 63, 399-402.

Bolte, H.-D. (1978). Immunologic investigation in patients with cardiomyopathies. In Cardiomyopathy and Myocardial Biopsy, pp. 251-255. Ed. by M. Kaltenbach, F. Loogen and E. G. J. Olsen. Springer Verlag, Berlin, Heidelberg, New York.

Bouhour, J. B., Petitier, H., de Lajartre, A. Y., Almazor, M., Nicolas, G., and Horeau, J. (1976). La biopsie myocardique dans les myocardiopathies congestives en apparence primitives. Archives des Maladies du Coeur et des Vaisseaux, 69, 485-494.

Brockington, I. F., and Olsen, E. G. J. (1973). Löffler's endocarditis and Davies' endomyocardial fibrosis. American Heart fournal, 85, 308-322.

Brooksby, I. A. B., Coltart, D. J., and Webb-Peploe, M. M. (1975). Progress in endomyocardial biopsy. Modern Concepts of Cardiovascular Disease, 44, 65-69.

Brooksby, I. A. B., Jenkins, B. S., Coltart, D. J., WebbPeploe, M. M., and Davies, M. J. (1974). Left ventricular endomyocardial biopsy. Lancet, 2, 1222-1225.

Caves, P. K., Schulz, W. P., Dong, E., Jr., Stinson, E. B., 
and Shumway, N. E. (1974a). New instrument for transvenous cardiac biopsy. American fournal of Cardiology, 33, 264-267.

Caves, P. K., Stinson, E. B., Billingham, M. E., and Shumway, N. E. (1974b). Serial transvenous biopsy of the transplanted human heart. Improved management of acute rejection episodes. Lancet, 1, 821-826.

Goodwin, J. F. (1973). Primary myocardial disease. Spectrum of cardiomyopathy and current classification. Singapore Medical fournal, 14, 358-362.

Harmjanz, D., Reale, E., Luciano, L., and Ostertag, P. (1971). Die Endomyokardbiopsie als Hilfsmittel in der Diagnostik von Myokarderkrankungen. Presented at 77 Tagung der Deutschen Geselschaft für Innere Medizin, April 22. (Cited by Sekiguchi, M. (1974). Fournal of Molecular and Cellular Cardiology, 6, 111-122.)

Kin, G., Combes, S., Miray, D., and Grosgogeat, Y. (1973). $\mathrm{La}$ biopsie endomyocardique. Technique, résultats et indications. Nouvelle Presse Médicale, 2, 3117-3120.

Konno, S., and Sakakibara, S. (1963). Endomyocardial biopsy. Diseases of the Chest, 44, 345-350.

Kuhn, H., Breithardt, G., Knieriem, H.-J., Loogen, F., Both, A., Schmidt, W. A. K., Stroobandt, R., and Gleichmann, U. (1975). Die Bedeutung der endomyokardialen Katheterbiopsie für die Diagnostik und die Beurteilung der Prognose der kongestiven Kardiomyopathie. Deutsche medizinische Wochenschrift, 100, 717-723.

Larter, W. E., Allen, H. D., Sahn, D. J., and Goldberg, S. J. (1976). The asymmetrically hypertrophied septum. Further differentiation of its causes. Circulation, 53, 19-27.

MacKay, E. H., Littler, W. A., and Sleight, P. (1974). Assessment of value of catheter biopsy of the heart (abstract). British Heart Fournal, 36, 404.

MacKay, E. H., Littler, W. A., and Sleight, P. (1978). Critical assessment of diagnostic value of endomyocardial biopsy. British Heart fournal, 40, 69-78.

Maron, B. J., Edwards, J. E., Ferrans, V. J., Clark, C. E., Lebowitz, E. A., Henry, W. L., and Epstein, S. E. (1975). Congenital heart malformations associated with disproportionate ventricular septal thickening. Circulation, 52, 926-932.

Müller, S. A., Müller, P., and Richter, G. (1971). Herzbiopsie mit Katheter-Bioptom. Zeitschrift für die gesamte innere Medizin, 26, 107-113.

Oakley, C. M. (1975). The relation between function and causation in cardiomyopathy. Postgraduate Medical fournal, 51, 271-276.

Olsen, E. G. J. (1974). Diagnostic value of the endomyocardial bioptome. Lancet, 1, 658-660.

Olsen, E. G. J. (1975). Results of endomyocardial biopsy: histological, histochemical and ultrastructural analysis. Postgraduate Medical fournal, 51, 295-297.

Olsen, E. G. J. (1976). Diagnostic value of the endomyocardial bioptome (Annotation). American Heart fournal, 91, 398-399.

Olsen, E. G. J. (1977a). Myocardial biopsies. In Recent Advances in Cardiology, Chapter 13, pp. 349-367. Churchill Livingstone, Edinburgh and London.

Olsen, E. G. J. (1977b). Endomyocardial biopsies. Is patho- logical examination of use? (abstract). British Heart fournal, 39, 349.

Peters, T. J., Bloomfield, F. J., and Oakley, C. M. (1975). Biochemical studies on biopsies from normal and diseased cardiac tissue (abstract). Postgraduate Medical fournal, 51, 298.

Peters, T. J., Wells, G., Brooksby, I. A. B., Jenkins, B. S., Webb-Peploe, M. M., and Coltart, D. J. (1976). Enzymic analysis of cardiac biopsy material from patients with valvular heart-disease. Lancet, 1, 269-270.

Petitier, H., Bouhour, J. B., de Lajartre, A. Y., Crochet, D., Nicolas, G., and Horeau, J. (1976). La biopsie endomyocardique, innocuité et intérêt clinique. Une expérience de cinq ans. Archives des Maladies du Coeur et des Vaisseaux, 69, 1005-1011.

Richardson, P. J. (1974). King's endomyocardial bioptome. Lancet, 1, 660-661.

Richardson, P. J. (1975). Technique of endomyocardial biopsy-including a description of a new form of endomyocardial bioptome. Postgraduate Medical fournal, 51, 282-285.

Richardson, P. J., Olsen, E. G. J., Jewitt, D. E., and Oram, S. (1975). Percutaneous technique of left ventricular biopsy and comparison between right and left ventricular myocardial samples (abstract). British Heart fournal, 37, 556.

Roberts, W. C., Liegler, D. G., and Carbone, P. P. (1969). Endomyocardial disease and eosinophilia. A clinical and pathologic spectrum. American fournal of Medicine, 46, 28-42.

Sakakibara, S., and Konno, S. (1962). Endomyocardial biopsy. fapanese Heart fournal, 3, 537-543.

Sekiguchi, M., and Konno, S. (1969). Histopathological differentiation employing endomyocardial biopsy in the clinical assessment of primary myocardial disease. Fapanese Heart Fournal, 10, 30-46.

Sekiguchi, M., and Konno, S. (1971). Diagnosis and classification of primary myocardial disease with the aid of endomyocardial biopsy. Fapanese Circulation fournal, 35, 737-754.

Sekiguchi, M., Konno, S., Hasegawa, F., and Hirosawa, K. (1972/73). Some characteristic electron microscopic pictures of diseased myocardium obtained by endomyocardial biopsy. Bulletin of the Heart Institute fapan, 14, 30-52.

Somers, K., Hutt, M. S. R., Patel, A. K., and d'Arbela, P. G. (1971). Endomyocardial biopsy in diagnosis of cardiomyopathies. British Heart fournal, 33, 822-832.

Teare, D. (1958). Asymmetrical hypertrophy of the heart in young adults. British Heart fournal, 20, 1-8.

Torp, A. (1973). Endomyocardial biopsy. Scandinavian Fournal of Thoracic and Cardiovascular Surgery, 7, 253-261.

Van Noorden, S., Olsen, E. G. J., and Pearse, A. G. E. (1971). Hypertrophic obstructive cardiomyopathy, a histological, histochemical and ultrastructural study of biopsy material. Cardiovascular Research, 5, 118-131.

Requests for reprints to Dr E. G. J. Olsen, Department of Morbid Anatomy and Histopathology, National Heart Hospital, Westmoreland Street, London W1M 8BA. 